DOI: 10.46340/eppd.2020.7.6.39
Andrii Tarasov
ORCID ID: https://orcid.org/0000-0002-1968-4858
National university "Odesa law academy», Ukraine

\section{CONSTITUTIONAL AND LEGAL GUARANTEES FOR THE PROTECTION OF THE RIGHTS OF PARTICIPANTS IN THE APARTMENT BUILDING CO-OWNERS ASSOCIATION}

\author{
Андрій Тарасов \\ Національний університет "Одеська юридична академія», Україна \\ КОНСТИТУЦЙНО-ПРАВОВІ ГАРАНТІї \\ ЗАХИСТУ ПРАВ УЧАСНИКІВ ОБ'ЄДНАННЯ \\ СПІВВЛАСНИКІВ БАГАТОКВАРТИРНОГО \\ БУ ДИНКУ
}

\begin{abstract}
The article analyzes the state of constitutional and legal regulation of mechanisms for protecting the rights of co-owners of an apartment building. Legal guarantees for the protection of housing and property rights of citizens, enshrined in the current legislation, are given. The regulation of activities and the functional role of apartment building co-owners association are considered as a form of public associations and a separate institution of self-government and self-organization of citizens in order to implement and protect housing rights. The article describes the constitutional and legal framework and guarantees for the protection of the rights of participants in $A B C A$, the legal status of $A B C A$ as an independent subject of protecting the rights of citizens. The main directions of development of $A B C A$ in Ukraine, problems of legal regulation of their functioning are given. The issue of legal regulation and functioning of apartment building co-owners association is covered. Conclusions are given regarding the constitutional and legal justification of the protection of the rights of homeowners. In this context, the institution of the apartment building co-owners association as a form of public associations and a separate form of selfgovernment and self-organization of citizens for the implementation and protection of housing rights is considered. The topical issue of safe creation and functioning of ABCA in Ukraine is considered. Factors and main obstacles to the effectiveness of $A B C A$ are considered. The article also covers social factors, such as the lack of active participation of co-owners in the implementation and protection of their own housing rights. Emphasis is placed on the existing problems of dishonesty of the founders of apartment building co-owners association as a factor in numerous violations of the rights of co-owners. The problems are characterized of the main threats of violations of citizens' rights and the formation of the ground for the illegal activities of persons-participants of ABCA. The main prospects for the development of the ABCA institute in Ukraine and the main directions of their implementation are presented.
\end{abstract}

Keywords: protection of housing rights, public associations, apartment building co-owners association, constitutional and legal guarantees.

Постановка проблеми. Захист житлових прав $є$ природною складовою механізму їх реалізації, відтак засобам та формам юридичного захисту приділяється в науці особлива увага. В цьому світлі, сучасні гарантії захисту житлових прав об'єднання співвласників багатоквартирного будинку викликають особливий інтерес. Ефективність правового захисту прямо впливає на стан належного забезпечення всіх аспектів користування особою власним житлом на умовах його безпечності, доглянутості, раціонального використання, управління тощо.

Логічний зв'язок між ефективним забезпеченням житлових прав людини та загальним рівнем іiі життя $€$ очевидним. Саме тому захист прав має грунтуватись та функціонально придатному правовому 
підгрунті, та опиратись на достатні правові гарантії. Однак реальний стан справ очевидно є далеким від бажаного. Це виражено, серед іншого, в наявності гострих проблем економічного-правового та суто юридичного характеру в сфері забезпечення прав власників житла. При цьому, активно функціонуючий інститут об'єднань співвласників багатоквартирного будинку демонструє певні позитивні тенденції розвитку та поширення. Таким чином, в умовах доволі несприятливих юридичних умов, необхідним є детальне вивчення діючих механізмів захисту житлових прав співвласників багатоквартирних будинків. Вказаний напрям досліджень має слугувати основою необхідних зрушень в правовій сфері. Тож об'єм наукових досліджень в означеній темі підлягає систематичній актуалізації, що дозволить своєчасно реагувати на найбільш відчутні загрози захищеності житловим правам громадян.

Ступінь дослідження теми. Вивчення зазначеної проблематики здійснено в окремих дослідженнях таких вчених, як В. В. Луць, Є. О. Харитонов, М. К. Галянтич, І. В. Давидова, О. М. Берназ-Лукавецька, С. Л. Горьова, Л. Г. Паращук, Н. В. Мороз, Т. О. Цимбалістий, О. Б. Росоляк, О. Д. Крупчан та інші.

Метою статті $\epsilon$ дослідження конституційно-правових основ та гарантій захисту прав співвласників багатоквартирного будинку, дослідження механізму захисту прав учасників об'єднань співвласників багатоквартирного будинку (Далі - ОСББ) в Україні. Окремим напрямом дослідження $\epsilon$ проблематика застосування діючих правових положень щодо захисту житлових прав власників житла.

Виклад основного матеріалу. Багатоквартирні будинки є невід'ємним елементом сучасних міст, який набуває в якості форми забезпечення житлом все більшого поширення. Збільшення кількості населення у таких містах породжує не лише активізацію економічних процесів, але й зростаючу соціальну напругу, а відповідно і нові правові виклики. Природньо, що і захист прав співвласників багатоквартирних будинків набуває більшої актуальності.

Насамперед увага науковців навколо функціонування ОСББ має фокусуватись на суспільноправовій природі інституту: розвиненні ОСББ як форми участі громадян в управлінні власним житлом та захисті житлових прав; зміцненні зв'язків та механізмів взаємодії громадськості та кожного індивіда зокрема із державними інституціями щодо системного контролю за забезпеченням житлових прав громадян.

Основою захисту прав співвласників багатоквартирних будинків $€$ їх нормативно-правова регламентація. Насамперед має значення конституційно-правове закріплення вказаних прав. Так, відповідно до ст. 41 Конституції України ${ }^{1}$, кожному гарантовано право володіти, користуватися і розпоряджатися своєю власністю, якої не може бути позбавлений протиправно.

Порядок припустимого обмеження вказаного права передбачає чіткий перелік підстав. Такі підстави встановлюються насамперед в судовому порядку. При цьому, відповідно до ст. 55 Основного Закону, кожному гарантовано право оскаржувати в суді рішення, дії чи бездіяльність органів державної влади, органів місцевого самоврядування, посадових і службових осіб, звернутись за захистом своїх прав до Уповноваженого Верховної Ради України з прав людини, або із конституційною скаргою до Конституційного Суду України (Далі - КСУ) у встановленому законом порядку. Наведені конституційні гарантії $є$ передумовою здійснення правового захисту прав людини та громадянина (зокрема, права власності).

Важливим елементом механізму захисту прав є гарантоване Конституцією право після використання всіх національних засобів юридичного захисту звертатися за захистом своїх прав і свобод до відповідних міжнародних судових установ чи до відповідних органів міжнародних організацій, членом або учасником яких є Україна. При цьому не менш вагомим інструментом захисту прав $\epsilon$ самозахист, що полягає у здійсненні конституційного права будь-якими не забороненими законом засобами захищати свої права і свободи від порушень і протиправних посягань.

Вагомим кроком узатвердженні вказаного права $\epsilon$ його тлумачення рішеннями Конституційного Суду України. Зокрема Рішенням КСУ від 25.12.1997 № 9-зп² встановлено, що ч. 1

\footnotetext{
${ }^{1}$ Конституиія Украӥни, 1996 (Верховна Рада України). Офіційний сайт Верховної Ради Украӥни <https://zakon.rada.gov.ua/laws/show/254\%D0\%BA/96-\%D0\%B2\%D1\%80?find=1\&text=\%D1\%94\%D0\%B2\% D1\%80\#w1_1> (2020, листопад, 12).

${ }^{2}$ Рішення Конституційного Суду Украйни у справі за конституиійним зверненням громадян Проченко Раїси Миколаївни, Ярошенко Поліни Петрівни та інших громадян щуодо офіційного тлумачення статей 55, 64, 124 Конституції України (справа за зверненнями жстелів міста Жовті Води), 1997 (Конституційний Суд України). Офіиійний сайт Верховної Ради <https://zakon.rada.gov.ua/laws/show/v009p710-97\#n54> (2020, листопад, 12).
} 
ст. 55 Конституції України слід розуміти таким чином, що кожному гарантується захист прав і свобод у судовому порядку. Суду забороняється відмовляти управосудді, якщо особа звертається за захистом своїх прав на законних підставах. Відмова суду у прийнятті позовних та інших заяв, скарг, оформлених відповідно до чинного законодавства, $є$ порушенням права на судовий захист, яке згідно зі статтею 64 Конституції України не може бути обмежене. При цьому додатково затверджується, що юрисдикція судів (повноваження вирішувати спори про право та інші правові питання) поширюється на всі правовідносини, що виникають у державі.

Також, згідно позиції КСУ, в ч. 2 ст. 55 Конституції України закріплено, що кожен має гарантоване державою право оскаржити в суді загальної юрисдикції рішення, дії чи бездіяльність будь-якого органу державної влади, органу місцевого самоврядування, посадових і службових осіб, якщо вважає, що такі рішення, дія чи бездіяльність порушують або ущемлюють відповідні права і свободи, чи перешкоджають їх здійсненню, у зв'язку з чим потребують правового захисту в суді. Така скарга безпосередньо розглядається судом незалежно від того, що прийнятим раніше законом міг бути встановлений інший порядок їх розгляду (оскарження до органу, посадової особи вищого рівня по відношенню до того органу і посадової особи, що прийняли рішення, вчинили дії або допустили бездіяльність). Використання зазначених позасудових засобів захисту не перешкоджає оскарженню цих рішень, дій чи бездіяльності до суду ${ }^{1}$. Загалом, судовий захист деякими вченими вважається основною юридичною гарантією прав і свобод людини ${ }^{2}$.

Конституційне право на захист знаходить більш розгорнуте закріплення в положеннях Цивільного Кодексу України [9]. Положеннями Кодексу закріплюється право на захист цивільних прав та інтересів у разі їх порушення, невизнання або оспорювання (ч.ч.1,2 ст. 15), способи захисту цивільних прав та інтересів (ч.2 ст. 16), захист цивільних прав та інтересів Президентом України, органами державної влади, органами влади Автономної Республіки Крим або органами місцевого самоврядування (ст. 17), захист цивільних прав нотаріусом (ст.18), самозахист цивільних прав (ст. 19) тощо. Також, відповідно статтею 4 Цивільного процесуального кодексу України ${ }^{3}$ конкретизується право на звернення до суду за захистом.

Однак, щодо співвласників багатоквартирного будинку існує певна специфіка застосування закріплених форм правового захисту. Насамперед відіграє значення характер власності, яким $€$ квартира, або нежитлове приміщення в багатоквартирному будинку. Вказаний тип житлових приміщень тісно пов'язує законні інтереси та майнові права співвласників, які мають здійснювати їх таким чином, щоб це не порушувало прав інших мешканців будинку, не створювало загрози цілісності, безпечності їх житлу тощо. Таким чином, низка прав співвласників багатоквартирного будинку складає комплекс колективних прав та обов'язків, які підлягають відповідному регулюванню та захисту.

3 метою забезпечення і захисту прав співвласників та дотримання їхніх обов'язків, належного утримання та використання спільного майна, забезпечення своєчасного надходження коштів для сплати всіх платежів, передбачених законодавством та статутними документами, створюються Об'єднання співвласників багатоквартирного будинку (Далі- ОСББ). Право громадян України на свободу об'єднання громадські організації для здійснення i захисту своїх прав і свобод та задоволення відповідних інтересів випливає з положень ст. 36 Конституції України. Вказане положення сьогодні конкретизовано Законом України «Про громадські об'єднання» ${ }^{4}$ від 22 березня 2012 року.

Вказаний вид об'єднань сьогодні може виступати самостійним суб'єктом захисту прав співвласників багатоквартирного будинку.

\footnotetext{
${ }^{1}$ Рішення Конституиійного Суду Украӥни у справі за конституиіийним зверненням громадянки Дзюби Галини Павлівни щзодо офіційного тлумачення частини другої статті 55 Конституиії України та статті 248-2 Цивільного процесуального кодексу України (справа громадянки Дзюби Г. П. щзодо права на оскарження в суді неправомірних дій посадової особи), 1997 (Конституційний Суд України). Офіційний сайт Верховної Ради <https://zakon.rada.gov.ua/laws/show/v006p710-97\#Text> (2020, листопад, 12).

${ }^{2}$ Цимбалістий, Т. О., Росоляк, О. Б. (2016). Органи конституційної юрисдикції в механізмі захисту прав та свобод людини і громадянина в Україні і Польщі. Актуальні проблеми правознавства, 1, 73-77. <http://nbuv.gov.ua/UJRN/aprpr_2016_1_16> (2020, листопад, 12).

${ }^{3}$ Цивільний процесуальний кодекс України, 2004 (Верховна Рада України). Офіиійний сайт Верховної Ради України <https://zakon.rada.gov.ua/laws/show/1618-15?find=1\&text=захист\#Техt> (2020, листопад, 12).

4 Закон Про громадські об'єднання, 2012 (Верховна Рада України). Офіиійний сайт Верховної Ради Украӥни <https://zakon.rada.gov.ua/laws/show/4572-17\#Tеxt> (2020, листопад, 12).
} 
Постановою Верховного Суду № 815/219/17 від 14 березня 2018 року, зокрема, зазначено: «...реальний захист прав співвласників будинку (членів ОСББ) у певних випадках потребує звернення до суду. Відтак, невизнання за ОСББ самостійного права на звернення до суду в інтересах членів, призвело б до неможливості забезпечення і захисту прав співвласників будинку і стало б невиправданою перешкодою для досягнення мети об'єднання» ${ }^{1}$. Також, відповідно до п. 3.3 Рішення Конституційного Суду України у справі N 1-11/2003 від 10 червня 2003 року № 11-рп/2003: «Держава забезпечує захист прав усіх суб'єктів права власності як у тому, що є загальним для них, так і в його особливостях відповідно до законів, дія яких на них поширюється» ${ }^{2}$.

Відповідні положення щодо статусу ОСББ визначено Законом України «Про об'єднання співвласників багатоквартирного будинку» ${ }^{3}$. Фактично, даний інституту є різновидом об'єднання громадян та специфічною формою саморганізації. ОСББ $є$ юридичною особою, створеною власниками квартир та/або нежитлових приміщень багатоквартирного будинку (ч. 3 ст. 1 Закону). Однак створення ОСББ має відповідати саме правам та інтересам кожного окремого власника житлового чи нежитлового приміщення в будинку та меті захисту даних прав. Так, ст. 14 вказаного Закону гарантує кожному співвласнику вимагати від статутних органів захисту своїх прав та дотримання співвласниками правил добросусідства.

Сьогодні перспективам ОСББ в Україні надаються позитивні оцінки ${ }^{4}$, хоча в доктрині зазначаються незадовільні темпи розвитку інституту. Перелік проблем в сфері захисту прав власників житла, що $є$ учасниками ОСББ проявляються в багатьох напрямах та на різних фазах функціонування даного інституту. Недостатньо прозорими є фактичні алгоритми створення ОСББ. Поширеною проблемою $є$ невідповідність діяльності ОСББ інтересам власників квартир та/або нежитлових приміщень. Під питанням залишаються окремі аспекти ОСББ як суб'єкту захисту прав співвласників багатоквартирного будинку.

Висновки. Основоположні засади захисту прав особи випливають з їі конституційного права на захист. Власник житлового чи нежитлового приміщення в багатоквартирному будинку здійснює захист власних прав на свій розсуд та в межах, встановлених законодавством. Сьогодні офіційно визнаною та достатньо ефективною інституцією захисту прав співвласників багатоквартирного будинку ОСББ. Об'єднання можуть користуватись правом звернення до суду за захистом прав співвласників чи об'єднання. Ефективність ОСББ випливає, серед іншого, з об'єднання зусиль співвласників щодо ефективної реалізації та захисту своїх житлових прав. Розглянута тема пов'язана з актуальними питаннями забезпечення та захисту житлових прав. При цьому саме захист житлових прав громадян займає особливе місце в сучасній юридичній доктрині.

\section{References:}

1. Ofitsiynyy veb-sayt Ministerstva rozvytku hromad ta terytoriy Ukrayiny (2020) [Official website of the Ministry of Development of Communities and Territories of Ukraine (2020)]. 10 perevah stvorennya OSBB dlya spivvlasnykiv bahatokvartyrnykh budynkiv [10 advantages of creating condominiums for co-owners of apartment buildings] <https://www.minregion.gov.ua/press/news/10-perevag-stvorennya-osbb-dlya-spivvlasnykiv-bagatokvartyrnyhbudynkiv/> (2020, November, 12). [in Ukrainian].

2. Konstytutsiya Ukrayiny, 1996 (Verkhovna Rada Ukrayiny) [Constitution of Ukraine, 1996 (Verkhovna Rada of Ukraine)]. Ofitsiynyy sayt Verkhovnoyi Rady Ukrayiny [Official site of the Verkhovna Rada of Ukraine] <https://zakon.rada.gov.ua/laws/show/254\%D0\%BA/96-\%D0\%B2\%D1\%80?find=1\&text=\%D1\%94\%D0\%B2\% D1\%80\#w1_1> (2020, November, 12). [in Ukrainian].

3. Postanova № 815/219/17, 2018 (Verkhovnyy Sud Ukrayiny) [Resolution № 815/219/17, 2018 (Supreme Court of Ukraine)]. Ofitsiynyy sayt Verkhovnoyi Rady Ukrayiny [Official site of the Verkhovna Rada of Ukraine] <https://supreme.court.gov.ua/supreme/> (2020, November, 12). [in Ukrainian].

4. Zakon Pro hromadski obyednannya, 2012 (Verkhovna Rada Ukrayiny).Ofitsiynyy sayt Verkhovnoyi Rady Ukrayiny [Official site of the Verkhovna Rada of Ukraine] 〈https://zakon.rada.gov.ua/laws/show/4572-17\#Text> (2020, November, 12). [in Ukrainian].

\footnotetext{
${ }^{1}$ Постанова № 815/219/17, 2018 (Верховний Суд України). Офіційний сайт Верховного Суду Украӥни <https://supreme.court.gov.ua/supreme/> (2020, листопад, 12).

${ }^{2}$ Рімення по справі про мораторій на примусову реалізацію майна, 2003 (Конституційний Суд України). Офіційний сайт Верховної Ради <https://zakon.rada.gov.ua/laws/show/v011p710-03\#Tеxt> (2020, листопад, 12). 3 Там само.

${ }^{4}$ Офіційний веб-сайт Міністерства розвитку громад та територій України (2020). 10 переваг створення ОСББ для співвласників багатоквартирних будинків <https://www.minregion.gov.ua/press/news/10-perevag-stvorennyaosbb-dlya-spivvlasnykiv-bagatokvartyrnyh-budynkiv/> (2020, November, 12).
} 
5. Zakon Pro obyednannya spivvlasnykiv bahatokvartyrnoho budynku, 2001 (Verkhovna Rada Ukrayiny) [Law on the Association of Co-Owners of an Apartment Building, 2001 (Verkhovna Rada of Ukraine)]. Ofitsiynyy sayt Verkhovnoyi Rady Ukrayiny [Official site of the Verkhovna Rada of Ukraine] <https://zakon.rada.gov.ua/laws/show/2866-14\#Text> (2020, November, 12). [in Ukrainian].

6. Rishennya po spravi pro moratoriy na prymusovu realizatsiyu mayna, 2003 (Konstytutsiynyy Sud Ukrayiny) [Decision on the moratorium on the forced sale of property, 2003 (Constitutional Court of Ukraine)]. Ofitsiynyy sayt Verkhovnoyi Rady Ukrayiny [Official site of the Verkhovna Rada of Ukraine] <https://zakon.rada.gov.ua/laws/show/v011p710-03\#Text> (2020, November, 12). [in Ukrainian].

7. Rishennya Konstytutsiynoho Sudu Ukrayiny u spravi za konstytutsiynym zvernennyam hromadyan Protsenko Rayisy Mykolayivny, Yaroshenko Poliny Petrivny ta inshykh hromadyan shchodo ofitsiynoho tlumachennya statey 55, 64, 124 Konstytutsiyi Ukrayiny (sprava za zvernennyamy zhyteliv mista Zhovti Vody), 1997 (Konstytutsiynyy Sud Ukrayiny) [Decision of the Constitutional Court of Ukraine in the case on the constitutional appeal of citizens Protsenko Raisa Mykolayivna, Yaroshenko Polina Petrovna and other citizens on the official interpretation of Articles 55, 64, 124 of the Constitution of Ukraine (case on appeals of Zhovti Vody residents), 1997 (Constitutional Court of Ukraine)] Ofitsiynyy sayt Verkhovnoyi Rady Ukrayiny [Official site of the Verkhovna Rada of Ukraine] <https://zakon.rada.gov.ua/laws/show/v009p710-97\#n54> (2020, November, 12). [in Ukrainian].

8. Rishennya Konstytutsiynoho Sudu Ukrayiny u spravi za konstytutsiynym zvernennyam hromadyanky Dzyuby Halyny Pavlivny shchodo ofitsiynoho tlumachennya chastyny druhoyi statti 55 Konstytutsiyi Ukrayiny ta statti 248-2 Tsyvilnoho protsesualnoho kodeksu Ukrayiny (sprava hromadyanky Dzyuby H. P. shchodo prava na oskarzhennya $v$ sudi nepravomirnykh diy posadovoyi osoby), 1997 (Konstytutsiynyy Sud Ukrayiny) [Decision of the Constitutional Court of Ukraine in the case on the constitutional appeal of citizen Dzyuba Halyna Pavlivna on official interpretation of part two of Article 55 of the Constitution of Ukraine and Article 248-2 of the Civil Procedure Code of Ukraine (case of citizen Dzyuba GP on the right to appeal persons), 1997 (Constitutional Court of Ukraine)]. Ofitsiynyy sayt Verkhovnoyi Rady Ukrayiny [Official site of the Verkhovna Rada of Ukraine] <https://zakon.rada.gov.ua/laws/show/v006p710-97\#Text> (2020, November, 12). [in Ukrainian].

9. Tsyvilnyy kodeks Ukrayiny, 2003 (Verkhovna Rada Ukrayiny) [Civil Code of Ukraine, 2003 (Verkhovna Rada of Ukraine)]. Ofitsiynyy sayt Verkhovnoyi Rady Ukrayiny [Official site of the Verkhovna Rada of Ukraine] <https://zakon.rada.gov.ua/laws/show/435-15\#Text> (2020, November, 12). [in Ukrainian].

10. Tsyvilnyy protsesualnyy kodeks Ukrayiny, 2004 (Verkhovna Rada Ukrayiny) [Civil Procedure Code of Ukraine, 2004 (Verkhovna Rada of Ukraine)]. Ofitsiynyy sayt Verkhovnoyi Rady Ukrayiny [Official site of the Verkhovna Rada of Ukraine] <https://zakon.rada.gov.ua/laws/show/1618-15?find=1\&text=захист\#Техt> (2020, November, 12). [in Ukrainian].

11. Tsymbalistyy, T. O., Rosolyak, O. B. (2016). Orhany konstytutsiynoyi yurysdyktsiyi v mekhanizmi zakhystu prav ta svobod lyudyny i hromadyanyna v Ukrayini i Polshchi [Bodies of constitutional jurisdiction in the mechanism of protection of human and civil rights and freedoms in Ukraine and Poland]. Aktualni problemy pravoznavstva [Actual problems of jurisprudence], 1, 73-77. <http://nbuv.gov.ua/UJRN/aprpr_2016_1_16> (2020, November, 12). [in Ukrainian]. 